DOI: $\square$ https://doi.org/10.15407/techned2020.03.062

\title{
THE INFLUENCE OF STOCHASTIC ENERGY CHARACTER IN DISTRIBUTED GENERATIONSYSTEMS ON THEIR STABILITY
}

Journal

Publisher

ISSN

Issue

Pages
Tekhnichna elektrodynamika

Institute of Electrodynamics National Academy of Science of Ukraine 1607-7970 (print), 2218-1903 (online)

No 3, 2020 (May/June)

$62-68$

\section{Authors}

\section{K.S. Klen*, V.Ya. Zhuikov**}

National technical university of Ukraine "Igor Sikorsky Kyiv Polytechnic Institute",

Peremohy Ave. 37, Kyiv, 03056, Ukraine,

e-mail: ekateryna.osypenko@gmail.com

* ORCID ID : https://orcid.org/0000-0002-6674-8332

** ORCID ID : https://orcid.org/0000-0002-3338-2426

\begin{abstract}
Formulas for calculating the process of energy change, taking into account its random nature, in the space of two and three variables in distributed systems are given. A graph of a discrete mapping of the energy change process and a Lameri diagram are presented to investigate the stability of this process. It is noted that due to the stochastic nature of the energy change process, the system can leave the steady-state zone. The method of finding the differential of a random process with the Wiener component according to the Ito formula is presented. The technique of applying the law of the iterated logarithm to the Wiener process is presented, and graphs of its typical trajectories are shown both at the entire observation interval and around zero. The necessity of application in distributed generation systems the energy storage for ensuring their stable operation is substantiated. References 11, figures 8.
\end{abstract}

Key words: distributed generation systems, Heisenberg's uncertainty principle, storage battery, stochastic processes. 
Received: 17.10 .2019

Accepted: 17.02.2020

Published: 05.05.2020

\section{References}

1. Zhuikov V.Ya., Lukyanenko L.M., Mikolaiets D.A., Osypenko K.S., Stelyuk A.O., Tereshenko T.O., Yamnenko Yu.S. Improving the efficiency of renewable energy systems. Kyiv: Kafedra, 2018. 368 p. (Ukr)

2. Stognij B.S., Kyrylenko O.V., Prahovnyk A.V., Denisyuk S.P. The evolution of smart grids and their prospects in Ukraine. Tekhnichna Elektrodynamika. 2012. No 5. Pp. 50-52. (Ukr)

3. Zhuikov V.Ya., Osypenko K.S. Heisenberg uncertainty principle in estimating energy levels generated by renewable energy sources. Tekhnichna Elektrodynamika. 2017. No 1. Pp. 10-16. (Ukr) DOI:

https://doi .org/10.15407/techned2017.01.010

4. Zhuikov V.Ya., Osypenko K.S. Estimation of fractal dimension and transfer function of clouds. Mikrosistemy, elektronika ta akustyka. 2017. Vol. 22. No 5. Pp. 13-19. (Ukr) DOI: https: //doi.org/10.20535/2523-4455.2017.22.5.106578

5. Borodin A.N., Salminien Paavo. The Brownian Movement Handbook: Facts and Formulas. Saint-Petersburg: Lan, 2000.639 p. (Rus)

6. Measurements using power quality analyzers. URL: http://khomovelectro.ru/articles/izmere niya-s-pomoshchyu-analizatorov-kachestva-elektroenergii.html (accessed: 18.10.2019). (Rus)

7. Klymontovych Yu.L. Introduction to Open Systems Physics. Moskva: Yanus-K, 2002. 284 p. (Rus)

8. Kuznetsov D.F. Some questions of the theory of numerical solution of stochastic Ito differential equations. URL: http://diffjournal.spbu.ru/pdf/j011.pdf (accessed: 18.10.2019). (Rus)

9. Bulynskiy A.V., Shyryaev A.N. Theory of random processes. Moskva: Fizmatlit, 2005. 408 p. (Rus)

10. Laboratory of renewable energy sources. URL: https://www.lares.fer.hr/ (Accessed 18.10.2019).

11. Marcelo G. Molina. Distributed energy storage systems for applications in future smart grids. Sixth IEEE/PES Transmission and Distribution: Latin America Conference and Exposition (T\&D-LA). Montevideo, Uruguay, September 3-5, 2012. DOI:

https://doi.org/10.1109/TDC-LA.2012.6319051 
$\underline{\text { PDF }}$

@ $\Theta \Theta \odot$

This work is licensed under a Creative Commons Attribution-NonCommercial-NoDerivatives 4.0 International License 